\title{
Seropositivity for hepatitis B virus, vaccination coverage, and vaccine response in dentists from Campo Grande, Mato Grosso do Sul, Brazil
}

\author{
Sonia MF Batista/ ${ }^{+}$, Márcia SA Andreasi, Ana MT Borges*, Andréa SC Lindenberg**, \\ Anísio L Silva, Thiago D Fernandes, Edy F Pereira, Eline AM Basmage***, \\ Divina DP Cardoso*
}

\begin{abstract}
Departamento de Patologia, Centro de Ciências Biológicas e da Saúde, Universidade Federal de Mato Grosso do Sul, Cidade Universitária, 79070-900 Campo Grande, MS, Brasil *Instituto de Patologia Tropical e Saúde Pública, Universidade Federal de Goiás, Goiânia, GO, Brasil **Centro Especial de Doenças Infecciosas e Parasitárias, Hospital Dia, Nova Bahia, Campo Grande, MS, Brasil ***Laboratório Central de Saúde Pública de Mato Grosso do Sul, Campo Grande, MS, Brasil

This study investigated the seropositivity for hepatitis $B$ virus $(H B V)$, the vaccination index, and the vaccine response index in dentists from Campo Grande, MS. Blood samples from 474 dentists $163.7 \%$ women and $36.3 \%$ men), with a mean age of $38.5 \pm 10.5$ years were analyzed by enzyme-linked immunosorbent assay to detect the serological markers: $H B s A g$, anti-HBs, and anti-HBc. The HBsAg positive samples were tested for anti-HBc IgM, HBeAg, and anti-HBe. A total of 51 (10.8\%) dentists showed seropositivity for HBV. Three (0.6\%) were HBsAg/antiHBc/anti-HBe positive, $43(9.1 \%)$ were anti-HBc/anti-HBs positive, and $5(1.1 \%)$ had only anti-HBc. Viral DNA was detected by polymerase chain reaction in $9(17.6 \%)$ out of $51 \mathrm{HBV}$ seropositive samples. A vaccination index of 96.6\% (458/474) was observed, although 73.1\% (335/458) completed the three-dose schedule. Excluding 46 HBV seropositive individuals from 458 that reported vaccination, 412 were analyzed for vaccine response index. It was observed that $74.5 \%$ (307/412) were anti-HBs positive; this percentage increased to $79.1 \%$ when three doses were administered. The results showed a high vaccination index and a good rate of vaccine response; however, the failure in completing the three-dose schedule and the occurrence of HBV infection reinforce the need for more effective prevention strategies.
\end{abstract}

Key words: hepatitis B - dentists - vaccination - seroprevalence - Brazil

The hepatitis B virus (HBV) is a causal agent of hepatitis, which is asymptomatic in most individuals, but it can show features of fulminant, acute, or chronic hepatitis, considering that the last one might evolve to serious complications, such as cirrhosis and hepatocellular carcinoma (Ganem \& Prince 2004). Each year, from 500,000 to 1.2 million individuals die as a consequence of $\mathrm{HBV}$ infection (Lavanchy 2004). Studies carried out in the pre-vaccination era showed that HBV infection in dentists was about three to six times greater than in the general population (Feldman \& Schiff 1975, Smith et al. 1976). Since the manufacturing of the first vaccines against HBV in 1982, and with the increase in the vaccination coverage, the prevalence of infection has been gradually falling (Cleveland 1996, Mahoney et al. 1997). The hepatitis B vaccination coverage among dentists is highly variable and it is not yet compatible with the possible elimination of the occupational risk of HBV infection (Camilo 1998, Ammon et al. 2000, Rodrigues 2002, Martins \& Barreto 2003), consider-

Financial support: Secretaria de Estado de Saúde, Conselho Regional de Odontologia de Mato Grosso do Sul, Universidade Federal de Mato Grosso do Sul, Universidade Federal de Goiás + Corresponding author: sonata@nin.ufms.br

Received 20 October 2005

Accepted 3 April 2006 ing the fact that these professionals are in continuous exposure to blood or other fluids potentially contaminated with HBV (Cleveland \& Cardo 2003).

This study presents the seropositivity for HBV, the vaccination index, and the vaccine response index in dentists from Campo Grande, state of Mato Grosso do Sul (MS), Brazil. Furthermore, HBV infection and putative association with epidemiological features were also investigated, considering that there is no information about this population group in MS.

\section{MATERIALS AND METHODS}

Studied population - From 1222 dentists associated to the Regional Odontology Council (Campo Grande, Mato Grosso do Sul), 474 subjects were randomly selected and invited to participate in this study. This sample was considered sufficient to detect seropositivity for HBV infection of $20 \%$ with an accuracy of $3 \%$. The blood samples were collected between August 2003 and November 2004. The Ethical Committee of the Federal University of Mato Grosso do Sul approved the study protocol. Informed consents were obtained from all dentists and a standardized questionnaire was used to collect sociodemographic, epidemiological information, and vaccination data.

Detection of HBV serological markers - All blood samples were tested in duplicate, using a commercial immunoassay (DiaSorin, Italy), in order to detect the following serological markers: $\mathrm{HBsAg}$, anti-HBs, and anti-HBc. The HBsAg positive samples were also tested for anti- 
$\mathrm{HBc} \mathrm{IgM}, \mathrm{HBe} \mathrm{Ag}$, and anti-HBe. In accordance with the positivity criteria established by this kit, the anti-HBs positive samples had concentration of antibody higher than $10 \mathrm{mIU} / \mathrm{ml}$. In the present study, HBV infection was defined as the presence of the serological marker anti$\mathrm{HBc}$, associated or not with HBsAg or anti-HBs.

All participants were notified of the results by mail and were provided with an interpretation of their serological markers. The dentists with HBsAg positive serological test were referred for clinical evaluation.

Vaccination and vaccine response indices - All dentists that reported previous vaccination were considered for the vaccination index analysis. The subjects that reported previous vaccination and had no serological marker for HBV infection were considered for the vaccine response index analysis.

Viral DNA detection - The positive samples for $\mathrm{HBsAg}$, as well as those positive for anti-HBc associated or not with anti-HBs, were analyzed to detect viral DNA by polymerase chain reaction (PCR). The viral DNA was extracted from serum and amplified as described previously by Niel et al. (1994). The oligonucleotides used as primers were: PS1 5'CCATATTCTTGGGAACAAGA3' (nt 2826-2845), PS2 5'GGTCCCCAGTCCTCGAGAAG3' (nt 124-143), X1 5'ACCTCCTTTCCATGGCTGCT3' (nt 13631382), X2 5'TAGGCAGAGGTGAAAAAGTT3' (nt 18181837), C1 5'CTGTGGAGTTACTCTCGTTTTTGC3' (nt 1935-1958), C2 5'CTAACATTGAGATTCCCGAGATTG3' (nt 2432-2458), S2 5'GGGTTTAAATGTATACCCAAA GA3' (nt 841-819), PS4 5'ACACTCATCCTCAGG CCATGCAGTG3' (nt 3194-3218) (Niel et al. 1994, Gomes et al. 1996). In the first round of amplification, the primer pairs PS1-PS2, X1-X2, C1-C2, C1-PS2, PS1-S2 were used to amplify five $\mathrm{HBV}$ fragments. The negative samples were submitted to a second amplification (semi-nested PCR) using primer pairs PS1-PS2 and PS4-S2 for products of C1-PS2 and PS1-S2, respectively. The utilized PCR procedure is able to detect 100 copies per genome (Gomes SA, pers. commun.).

Statistical analysis - The data were analyzed using the EPINFO 6.04 (Centers for Disease Control and Prevention, Atlanta, GA, US, 1997) statistical software package. Chi-square test and Fisher's exact test with 95\% confidence intervals were used when appropriate. Results were considered significant when $\mathrm{p}$ value $<0.05$.

\section{RESULTS}

Among 474 dentists, 302 (63.7\%) were female and 172 $(36.3 \%)$ were male. Their age ranged from 21 to 69 years, with a mean age of $38.5 \pm 10.5$ years. More than $50 \%$ of the dentists were married $(60.7 \%)$, had a professional specialty $(57.4 \%)$, had up to 20 years of professional practice $(72.1 \%)$, and practiced in both private clinics and public service $(65.5 \%)$.

According to the results of serological tests performed on 474 dentists, 51 (10.8\%) showed seropositivity for HBV infection. Three subjects $(0.6 \%)$ were $\mathrm{HBsAg} / \mathrm{anti}-\mathrm{HBc} /$ anti-HBe positive, $43(9.1 \%)$ were anti-HBc/anti-HBs positive, and five $(1.1 \%)$ presented reactivity for only antiHBc (Table I).
TABLE I

Serological markers among dentists in Campo Grande, Mato Grosso do Sul, Brazil, 2003/2004

\begin{tabular}{lcr}
\hline Serological markers & Positive/Total & $\%$ \\
\hline Seropositivity for hepatitis B virus & $51 / 474$ & 10.8 \\
HBsAg/anti-HBc/anti-HBe & $3 / 474$ & 0.6 \\
Anti-HBc & $5 / 474$ & 1.1 \\
Anti-HBc/anti-HBs & $43 / 474$ & 9.1 \\
Seropositivity to vaccine & & \\
Anti-HBs alone & $307 / 412$ & 74.5 \\
\hline
\end{tabular}

A significant association was observed between HBV infection and older age $\left(\chi^{2}=17.97 ; \mathrm{p}=0.00\right)$ and longer duration of professional career (years of professional practice $\left(\chi^{2}=12.65 ; p=0.00\right)$. A higher frequency of HBV infection was also found among dentists who informed an irregular use of protective glasses ( 18.6 vs $9 \% \mathrm{p}=0.01$ ) and clothing (18.3 vs $8.9 \% \mathrm{p}=0.01)$, in comparison to their counterparts.

HBV-DNA was detected in 9/51(17.6\%) of HBV seropositive samples. All HBsAg positive samples, 3/3 (100\%), were also positive for HBV-DNA in the first amplification reaction. Moreover, HBV-DNA was detected in $1(n=5)$ and $6(n=43)$ of anti-HBc (sole marker) and anti-HBc/antiHBs positive samples, respectively. Five out of 48 samples with anti-HBc, associated or not with anti-HBs, presented positivity only in the second amplification reaction (Table II).

Among the participants of this study, 458/474 (96.6\%) reported vaccination against HBV. From these, 335/458 $(73.1 \%)$ received the three recommended doses and only $26 / 458(5.7 \%)$ reported a post-vaccination serological test for anti-HBs. HBV vaccination was significantly lower among dentists who informed older age ( 91.5 vs $99.2 \%$, p $=0.00)$ and older duration of professional practice $(91.7$ vs $99.4 \%, \mathrm{p}=0.00$ ).

Excluding 46 individuals that presented any serological marker for HBV infection from those 458 subjects who reported previous vaccination, 412 dentists were analyzed for the vaccine response index (Table I). It was observed that $307(74.5 \%)$ subjects presented seropositivity for the $\mathrm{HBV}$ vaccine; taking into consideration the three doses, the index increased to $79.1 \%$, which was significantly higher than those who received one or two doses of the vaccine $(p=0.04)$.

No significant difference in the vaccine response index was observed in relation to gender, vaccination schedule, vaccine administration route, and vaccine site ( $\mathrm{p}$ > 0.05 ). For dentists who received the third dose of the vaccine one year before the participation in this study, the vaccine response index was $95.7 \%$, significantly higher than those who completed the three-dose schedule in a period longer than one year before $(76 \%)(p=0.00)$. Among 458 dentists who reported previous vaccination, 105 subjects were negative for all serological markers tested. From these, $97(92.4 \%)$ received the last dose of the vaccine in a period longer than one year before the participation in this study. 
TABLE II

Positivity for DNA hepatitis B virus among dentists in Campo Grande, Mato Grosso do Sul, Brazil, who presented seropositivity for HBV, 2003/2004

\begin{tabular}{|c|c|c|c|c|c|c|c|}
\hline \multirow{2}{*}{$\begin{array}{l}\text { Sample } \\
\text { (serological } \\
\text { markers) }\end{array}$} & \multicolumn{5}{|c|}{ 1st amplification } & \multicolumn{2}{|c|}{ 2nd amplification } \\
\hline & PS1-PS2 & $\mathrm{X} 1-\mathrm{X} 2$ & $\mathrm{C} 1-\mathrm{C} 2$ & C1-PS2 & PS1-S2 & PS1-PS2 & PS4-S2 \\
\hline 1(HBsAg) & & $(+)$ & & & & & \\
\hline 2(HBsAg) & & & $(+)$ & $(+)$ & & & \\
\hline 3(HBsAg) & & & $(+)$ & $(+)$ & & & \\
\hline $4($ anti-HBc $)$ & & & & & & $(+)$ & \\
\hline 5(anti-HBc) & & $(+)$ & & & & $(+)$ & \\
\hline 6(anti-HBc) & & & & & & $(+)$ & \\
\hline 7(anti-HBc) & & & & & & $(+)$ & \\
\hline $8($ anti-HBc $)$ & & & & & & $(+)$ & \\
\hline 9(anti-HBc) & & & & & & $(+)$ & \\
\hline
\end{tabular}

$a$ : the samples 1-3 were HBsAg/anti-HBc/anti-HBe positive; the samples 5-9 were anti-HBc/anti-HBs positive.

\section{DISCUSSION}

The present study showed that seropositivity for HBV infection among dentists (10.8\%) from Campo Grande, MS, was higher than that recorded among blood donors $(9.4 \%)$ in the same city (Aguiar et al. 2001). In dentists from the other regions of Brazil, the infection rates ranged from 10 to $17.9 \%$ (Ozaki et al. 1998, Camilo 1998, Rodrigues 2002). On the other hand, it was observed $9 \%$ of seropositivity for HBV infection among dentists from the United States (Cleveland 1996) and 7\% among dentists from Berlin, in Germany (Ammon et al. 2000).

Studies carried out among dentists in the pre-vaccination years showed $15 \%$ of seropositivity for HBV infection in the United States (Gruninger et al. 1991) and 23.3 to $31.2 \%$ in Brazil (Ottoni et al. 1995, Baldy 1995).

In this study, HBV seropositivity significantly increased with age and duration of professional practice. This is in accordance with other studies (Ottoni et al. 1995, Cleveland 1996, Camilo 1998, Rodrigues 2002). Consistent with previous findings (Ammon et al. 2000), our findings highlight the role of protective glasses and clothing use as preventive measures for HBV infection among dentists.

Among $51 \mathrm{HBV}$-seropositive dentists, 46 subjects reported previous HBV vaccination. Among these, 33 received the three recommended doses. It was considered that the infection had possibly occurred before the vaccination; or, yet, that these professionals were non-responders to the vaccine and, in the susceptible condition, ran the same risk of acquiring infection as the non-vaccinated subjects.

The frequency of HBV-DNA in both anti-HBc/antiHBs and anti-HBc (sole marker) positive groups is in accordance with the literature (Gomes et al. 1996, Bréchot et al. 2001, Minuk et al. 2005) and suggest that HBV infection might persist in individuals with a serological profile of resolved infection.

In the present study, the majority of the dentists $(96.6 \%)$ reported HBV vaccination, although only $73.1 \%$ completed the three-dose schedule. Nevertheless, the percentage of adhesion of these professionals to $\mathrm{HBV}$ immunization is considered higher than those observed in other studies (Cleveland 1996, Camilo 1998, Ammon et al. 2000) as among health-care workers (HCWs) (Silva et al. 2003, 2005). In Brazil studies have shown vaccination indices similar to those observed in the present study (Rodrigues 2002, Martins \& Barreto 2003). In spite of high compliance with $\mathrm{HBV}$ vaccination, more efforts are necessary for dentists to receive full-scheme (three vaccine doses).

HBV vaccination was lower among dentists who informed older age and longer duration of professional practice, which is in accordance with previous studies (Cleveland 1996, Camilo 1998, Rodrigues 2002, Martins \& Barreto 2003).

In this study, among those with full-scheme vaccination, only $5.7 \%$ subjects reported the post-vaccination test, which is in agreement with other studies (Cleveland et al. 1994, Sorabjee \& Garje 2004, Saffar et al. 2005, Oh et al. 2005). These data suggest that dentists should be counseled to detect anti-HBs one or two months after completing the three-dose vaccination series.

Vaccine response was higher among subjects who completed the three-dose schedule, in comparison with those who only received one or two vaccine doses. Furthermore, the frequency of vaccine response was significantly lower among older subjects, in accordance with other authors (Ferraz et al. 1992, Cleveland et al. 1994, Cuevas et al. 1997, Averhoff et al. 1998, Arca et al. 1998, Silva et al. 2005). Consistent with previous investigations (Zumaeta et al. 1995, Prakash et al. 2000), differences in vaccine response were not observed regarding gender, smoking status, vaccination schedule, vaccine administration route, and vaccine site, although females and nonsmokers are more likely to demonstrate high vaccine response (Cleveland et al. 1994, Averhoff et al. 1998).

After vaccination, a gradual decline in anti-HBs titers is frequently found (Floreani et al. 2004). Corroborating other studies (Ferraz et al. 1992, Oliveira 1997, Cuevas et al. 1997, Turchi et al. 1997, Arca et al. 1998, Lopes et al. 2001), we observed that the vaccine response index was significantly higher among dentists who received the third dose up to one year before the interview, compared to their counterparts. 
In our study, about one third of dentists were nonresponders for HBV immunization (whose susceptible status was generally unknown). Therefore, these subjects are still under risk for $\mathrm{HBV}$ infection, especially due to the background prevalence reported in MS (Motta-Castro et al. 2003, 2005). To effectively curb HBV infection in this setting, prevention programs must be reinforced, and the relevance of a complete vaccination schedule must be underlined.

\section{REFERENCES}

Aguiar JI, Aguiar E, Paniago A, Cunha R, Galvão L, Daher R 2001. Prevalence of antibodies to hepatitis B core antigen in blood donors in the Middle West region of Brazil. Mem Inst Oswaldo Cruz 96: 185-187.

Ammon A, Reichart PA, Pauli G, Petersen LR 2000. Hepatitis $\mathrm{B}$ and $\mathrm{C}$ among Berlin dental personnel: incidence, risk factors, and effectiveness of barrier prevention measures. Epidemiol Infect 125: 407-413.

Arca M, Gadea FA, Gabjoud JC, Labalta CR, Oertlinger S, Sanchez LM 1998. Tamizaje de marcadores para hepatitis B pre y post-vacunación en el hospital de C. Del Uruguay, Argentina. Acta Bioquím Clin Latinoam 32: 377-382.

Averhoff F, Mahoney F, Coleman P, Schatz G, Hurwitz E, Margolis H 1998. Immunogenicity of hepatitis B vaccines implications for persons at occupational risk of hepatitis B virus infection. Am J Prev Med 15: 1-8.

Baldy JLS 1995. Hepatite B em 250 Dentistas do Norte do Paraná: Prevalência da Infecção, Medidas Preventivas Adotadas e Resposta Imune, de 135 Suscetíveis, à Vacina Recombinante Belga Administrada em Esquema de Três Doses (2 mcg) por Via Intradérmica, PhD Thesis, Faculdade de Medicina, Universidade Federal de Minas Gerais, Belo Horizonte, 285 pp.

Bréchot C, Thiers V, Kremsdorf D, Nalpas B, Pol S, PaterliniBréchot P 2001. Persistent hepatitis B virus infection in subjects without hepatitis B surface antigen: clinically significant or purely "occult"? Hepatology 34: 194-203.

Camilo RS 1998. Prevalência das Hepatites $B$ e $C$ nos Cirurgiões-Dentistas da Faculdade de Odontologia da UFRJ, PhD Thesis, Faculdade de Odontologia, Universidade Federal do Rio de Janeiro, Rio de Janeiro, 96 pp.

Cleveland JL 1996. Hepatitis B vaccination and infection among U.S. dentists, 1983-1992. J Am Dent Assoc 127: 1385-1390.

Cleveland JL, Cardo DM 2003. Occupational exposures to human immunodeficiency virus, hepatitis B virus, and hepatitis $\mathrm{C}$ virus: risk, prevention, and management. Dent Clin North Am 47: 681-696.

Cleveland JL, Siew C, Lockwood SA, Gruninger SE, Chang SB, Neidle EA, Russell CM 1994. Factors associated with hepatitis B vaccine response among dentists. J Dent Res 73: 1029-1035.

Cuevas H, Fajardo H, Mejía G, Neira M, Gutiérrez M, De La Hoz F, Raad J 1997. Respuesta a la vacunación contra la hepatitis B en trabajadores de la salud del Hospital San Juan de Dios de Santa Fé de Bogotá. Acta Med Colomb 22: 61-66.

Feldman RE, Schiff ER 1975. Hepatitis in dental professionals. J Am Méd Assoc 232: 1228-1230.
Ferraz MLG, Silva AE, Yamamoto M, Guimarães RX 1992. Hepatitis B vaccine - proposal for a standardized assessment of immune response. Rev Inst Med Trop São Paulo 34: 137-140.

Floreani A, Baldo V, Cristofoletti M, Renzulli G, Valeri A, Zanetti C, Trivello R 2004. Long-term persistence of anti-HBs after vaccination against $\mathrm{HBV}$ : an 18 years experience in health care workers. Vaccine 22: 607-610.

Ganem D, Prince AM 2004. Hepatitis B virus infection - Natural history and clinical consequences. $N$ Engl J Med 350: 1118-1129.

Gomes SA, Yoshida CTF, Niel C 1996. Direction of hepatitis B virus DNA in hepatitis B surface antigen-negative serum by polymerase chain reaction: elevation of different primer pairs and conditions. Acta Virol 40: 133-138.

Gruninger SE, Siew C, Chang SB, Clayton R, Kuo G, Verrusio AC, Neidle EA 1991. Hepatitis B, C and HIV infection among dentists. J Dent Research 70: 532.

Lavanchy D 2004. Hepatitis B virus epidemiology, disease burden, treatment, and current and emerging prevention and control. J Viral Hepat 11: 97-107.

Lopes CLR, Martins RMB, Teles AS, Silva SA, Maggi PS, Yoshida CFT 2001. Perfil soroepidemiológico da infecção pelo vírus da hepatite $\mathrm{B}$ em profissionais das unidades de hemodiálise de Goiânia-Goiás, Brasil Central. Rev Soc Bras Med Trop 34: 543-548.

Mahoney FJ, Stewart K, Hu H, Coleman P, Alter MJ 1997. Progress toward the elimination of hepatitis B virus transmission among health care workers in the United States. Arch Intern Med 157: 2601-2605.

Martins AMEBL, Barreto SM 2003. Vacinação contra a hepatite B entre cirurgiões dentistas. Rev Saúde Pública 37: 333338.

Minuk GY, Sun D, Uhanova J, Zhang M, Caouette S, Nicolle LE, Gutkin A, Doucette K, Martin B, Giulivi A 2005. Occult hepatitis B virus infection in a North American community-based population. J Hepatol 42: 480-485.

Motta-Castro ARC, Martins RMB, Yoshida CFT, Teles SA, Paniago AM, Lima KMB, Gomes SA 2005. Hepatitis B virus infection in isolated Afro-Brazilian communities. $J$ Med Virol 77: 188-193.

Motta-Castro ARC, Yoshida CFT, Lemos ERS, Oliveira JM, Cunha RV, Lewis-Ximenez LL, Cabello PH, Lima KMB, Martins RMB 2003. Seroprevalence of hepatitis B virus infection among an afro-descendant community in Brazil. Mem Inst Oswaldo Cruz 98: 13-17.

Niel C, Moraes MTB, Gaspar AMC, Yoshida CFT, Gomes SA 1994. Genetic diversity of hepatitis B virus strains isolated in Rio de Janeiro, Brazil. J Med Virol 44: 180-186.

Oh HS, Yi SE, Choe KW 2005. Epidemiological characteristics of occupational blood exposures of healthcare workers in a university hospital in South Korea for ten years. J Infect 60: 269-275.

Oliveira PMC 1997. Segmento após 5 Anos de Três Diferentes Esquemas de Vacinação contra a Hepatite B em Profissionais da Área de Saúde, PhD Thesis, Escola Paulista de Medicina, Universidade Federal de São Paulo, São Paulo, 85 pp.

Ottoni CMC, Penna FJ, Oliveira CG, Souza CJCG 1995. 
Prevalência de marcadores sorológicos de hepatite B em estudantes de odontologia e dentistas em Belo Horizonte, Brasil. Bol Oficina Sanit Panam 118: 108-114.

Ozaki KS, Fontes CJF, Fortes HM, Souto FJD 1998. Infecção pelos vírus das hepatites $\mathrm{B}$ e C entre odontólogos de Cuiabá e Várzea Grande, estado de Mato Grosso. Rev Patol Trop 27: 177-184.

Prakash C, Bhatia R, Kumari S, Verghese T, Datta KK 2000. Response to hepatitis $\mathrm{B}$ vaccination in high risk population. J Commun Dis 32: 17-21.

Rodrigues VC 2002. Hepatite B no Município de Ribeirão Preto (SP): um Estudo Envolvendo Cirurgiões-Dentistas e Auxiliares Odontológicos, MSc Thesis, Faculdade de Medicina de Ribeirão Preto, Universidade de São Paulo, Ribeirão Preto, 84 pp.

Saffar MJ, Jooyan AR, Mahdavi MR, Khalilian AR 2005. Hepatitis B vaccination status in health-care workers. Indian $J$ Gastroenterol 24: 82-83.

Silva PA, Fiaccadori FS, Borges AMT, Silva AS, Daher RR, Martins RMB, Cardoso DDP 2005. Seroprevalence of hepatitis $\mathrm{B}$ virus infection and seroconvertion to anti-HBsAg in laboratory staff in Goiânia, Goiás. Rev Soc Bras Med Trop 38: 153-156.

Silva RJO, Athayde MJPM, Silva LGP, Braga EA, Giordano MV, Pedrosa ML 2003. Vacinação anti-hepatite B em profissionais de saúde. J Bras Doenças Sex Transm 15: 5155 .

Smith JL, Maynard JE, Berquist KR, Doto IL, Webster HM, Sheller MJ 1976. Comparative risk of hepatitis B among physicians and dentists. J Infect Dis 133: 705-706.

Sorabjee JS, Garje R 2004. Vaccinated but not immunized: protection against hepatitis B in medical staff in the developing world. J Hosp Infect 58: 164-165.

Turchi MD, Martelli CMT, Ferraz ML, Silva AE, Cardoso DDP, Martelli P, Oliveira LJWA 1997. Immunogenicity of low-dose intramuscular and intradermal vaccination with recombinant hepatitis B vaccine. Rev Inst Med Trop São Paulo 39: 15-20.

Zumaeta VE, Figueroa BR, Ferrándiz QJ, Griego AG, Albajés VR 1995. Vacuna recombinante contra la hepatitis viral B en trabajadores de la salud del Instituto Peruano de la Seguridad Nacional. Rev Gastroenterol Peru 15: 135-139. 